\title{
Direct reprogramming into interneurons: potential for brain repair
}

\author{
Maria Pereira $^{1} \cdot$ Marcella Birtele $^{1} \cdot$ Daniella Rylander Ottosson $^{1}$ (i)
}

Received: 29 October 2018 / Revised: 11 June 2019 / Accepted: 13 June 2019 / Published online: 27 June 2019

(c) The Author(s) 2019

\begin{abstract}
The brain tissue has only a limited capacity for generating new neurons. Therefore, to treat neurological diseases, there is a need of other cell sources for brain repair. Different sources of cells have been subject of intense research over the years, including cells from primary tissue, stem cell-derived cells and reprogrammed cells. As an alternative, direct reprogramming of resident brain cells into neurons is a recent approach that could provide an attractive method for treating brain injuries or diseases as it uses the patient's own cells for generating novel neurons inside the brain. In vivo reprogramming is still in its early stages but holds great promise as an option for cell therapy. To date, both inhibitory and excitatory neurons have been obtained via in vivo reprogramming, but the precise phenotype or functionality of these cells has not been analysed in detail in most of the studies. Recent data shows that in vivo reprogrammed neurons are able to functionally mature and integrate into the existing brain circuitry, and compose interneuron phenotypes that seem to correlate to their endogenous counterparts. Interneurons are of particular importance as they are essential in physiological brain function and when disturbed lead to several neurological disorders. In this review, we describe a comprehensive overview of the existing studies involving brain repair, including in vivo reprogramming, with a focus on interneurons, along with an overview on current efforts to generate interneurons for cell therapy for a number of neurological diseases.
\end{abstract}

Keywords Transdifferentiation - Viral injections · Neuronal conversion · Intracerebral injections · Mice · Cell therapy · Parvalbumin $\cdot$ Neurodegenerative diseases $\cdot$ Neuropsychiatric disorders $\cdot$ Dopamine $\cdot$ iPSC $\cdot$ ESCs $\cdot$ iNs

\section{Cell transplantation and brain repair}

Efforts to replace damaged neurons in the brain through transplantation of various cell sources have been carried out over decades for a number of neurological diseases. First attempts date back to the 80 's, when Swedish scientists' research led to a clinical trial, in which midbrainderived fetal cells were transplanted into the brain of Parkinson's disease (PD) patients. The cells survived transplantation and induced symptomatic relief in some patients, integrating in the host brain and re-innervating the striatum, where they released the neurotransmitter dopamine $([1,2]$; reviewed in [3]). Fetal neuronal transplants from whole ganglionic eminences have also been attempted to treat patients with Huntington's disease

Daniella Rylander Ottosson

daniella.ottosson@med.lu.se

1 Department of Experimental Medical Science and Lund Stem Cell Center BMC, Lund University, 22141 Lund, Sweden
(HD), providing several years of improvement and stability, although not a cure to the disease [4]. Despite the potential for brain repair of fetal cells, a limited availability of tissue and important ethical concerns, limited the use of therapies involving these cells as they cannot be available for a large number of patients. There was hence a need for developing other cell sources that could be used for this purpose. Beside the cell of origin, the host environment needs to be considered for transplant integration $[2,5]$. In this context, GABAergic interneurons (INs) that derive from medial ganglionic eminence (MGE) showed the capacity to disperse and integrate into neural circuits in the postnatal brain (reviewed in [6, 7]). Recent advances in cellular biology and improvement of culture methodologies have led to the development of protocols that allow the use of embryonic stem cells (ESCs), pluripotent cells that can be obtained from human blastocysts [8], expanded in vitro and differentiated into specific types of neurons or neural progenitors for cell replacement. hESCs have been successfully used as a source of neurons that show molecular, biochemical and functional traits of bonafide 
dopaminergic neurons (DA), generated using extrinsic patterning cues that mimic fetal brain development $[9,10]$. Also layer-specific cortical neurons [11, 12], GABAergic and serotoninergic neurons [13], motor neurons [14, 15], peripheral neurons $[16,17]$ and neural progenitor cells have been generated in vitro from hESCs $[18,19]$. Reports of human stem cell differentiation into MGE-derived INs, such as Parvalbumin (PV)- and Somatostatin (SST)-positive cells, haven't always shown high efficacy, even when long-term co-culture was used [20, 21]. However, differentiation into INs has seen significant progress, with more efficient differentiation into subtype-specific groups of INs or forebrain-specific GABAergic INs [22-24].

Limitations associated with the use of ESCs for neuron derivation are related with the pluripotency of the starting cell. While this does not preclude their use in the clinic, extensive (and expensive) preclinical testing is required prior to use. Additionally, there are ethical considerations as well as issues related to high cost, patentability and commercialization of products derived from human embryos that could hamper the development of such therapies [25, 26].

In 2006, Takahashi and Yamanaka identified four factors $(O c t 3 / 4, K l f 4$, Sox 2 and Myc) that were sufficient to directly reprogram mouse adult somatic cells into an induced pluripotent stem cell state, generating the so-called induced pluripotent stem cells (iPSCs) [27]. This cell type could allow for patient-specific autologous grafts, lowering the risk of graft rejection and therefore circumventing the need for immunosuppression. Their potential use in the clinic could also raise less ethical concerns due to the autologous origin of the cells. Human iPSCs can be differentiated using similar protocols as the ones used for ESC differentiation, and generate subtype-specific neurons that survive transplantation [21, 28-30]. In addition to the cell therapy potential, iPSCs offer an unlimited source of patient-derived cells, which in principle can be differentiated into disease-relevant somatic cell types to create in vitro models of the disorder of interest [31].

Despite their potential for personalized treatments, iPSCs' use also raises concerns regarding the feasibility as a therapy for a large population of patients, as there would be important technical, regulatory and financial drawbacks, mostly related to their autologous origin. If using iPSCs from autologous sources, a more difficult standardization of manufacturing processes and consequently higher costs, could arise from such therapy [32].

Alternatives to transplantation of these sources involve the use of somatic cells that can be directly reprogrammed into fully functional mature neurons of specific subtypes without passing through the stage of pluripotency. In Fig. 1, we present an overview of the different cell sources that are considered for cell replacement in the brain and the respective pros and cons.

\section{Direct neuronal reprogramming}

\section{In vitro reprogramming}

In recent years and following the finding that somatic cells can be reprogrammed into pluripotency, many labs have also succeeded in directly switching the identity of one cell type to another, without going through a pluripotent state. By expression of appropriate transcriptional factors, with or without the assistance of specific environmental signals, fibroblasts were used for cellular reprogramming into cardiomyocytes, blood progenitor cells, hepatocytes, epiblast stem cells and neural progenitors [33-40], showing that adult somatic cells can be reprogrammed not only to pluripotency, but also into distantly related cell types.

In 2010, researchers showed that by overexpressing as few as three genes, Ascll, Brn2, and MytlL (ABM) in mouse embryonic and perinatal skin fibroblasts, these cells could be reprogrammed into neurons, termed induced neurons [41]. The same factors were also shown to convert human fibroblasts alone, or in combination with NeuroDl [42, 43]. This so-called direct reprogramming into neurons has today developed into a likely approach to obtain functional and subtype-specific neuronal cells that in turn might be used to replace those lost by insults such as in PD, spinal cord injury or psychiatric disorders [44, 45]. Induced neurons have a reduced risk of tumorigenic potential due to their non-pluripotent origin and have appealing advantages such as the fact that neurons can be generated from relatively easily obtainable cells like fibroblasts, the significant reduction in ethical concerns due to the autologous origin of the cells, and the lower risk of graft rejection. Besides that, they offer a faster and less labour-intensive option than that of iPSC.

Cellular reprogramming brought new insights into the neuroregenerative medicine field and proposed an appealing strategy to generate neurons of different subtypes. Their use as alternatives for cell therapy has been largely explored in the last decade. With the use of pro-neural and cell-typespecific transcription factors (TFs), as well as micro-RNAs and small molecules, several groups have shown that mouse and human fibroblasts and astrocytes can be reprogrammed into different types of neurons including glutamatergic, GABAergic, motor, sensory and DA neurons [44, 46-53], among others. Induced neurons have been generated in vitro and transplanted, showing survival and functional integration in the host brain $[44,47,54-56]$.

In vitro reprogramming techniques have also been used to generate GABAergic telencephalic neurons and GABAergic INs. Colasante et al. have shown that both mouse and human fibroblasts and iPSCs can be converted into cortical GABAergic INs upon transduction with a viral cocktail containing important factors for induction 


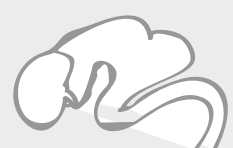

Fetal cells

Transplantation into patients has been proved safe and

PROS

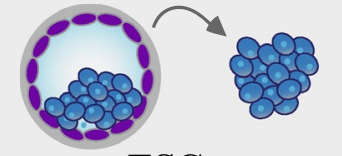

ESCs

Limitless source of neurons;

Existing differentiation protocols allow the generation of distinct neuronal subtypes.
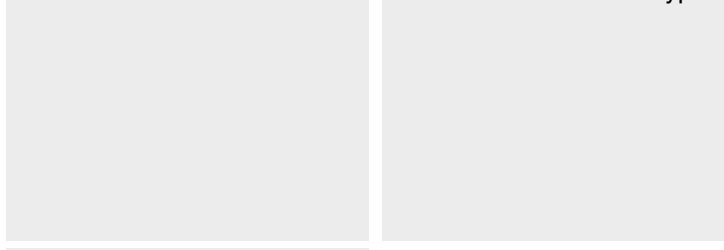

Tissue availability;

Ethical concerns due to the use of surplus fetuses.

Ethical issues due to the use of human embryos;

Pluripotent origin - risk of

\section{CONS}

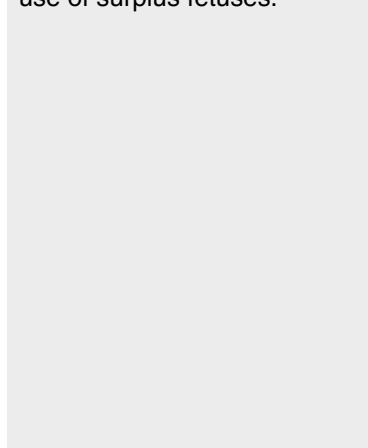

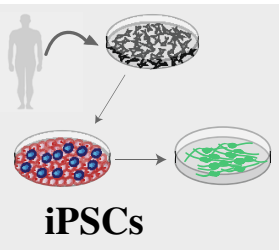

Limitless source of neurons;

Existing differentiation

protocols allow the generation

of distinct neuronal subtypes;

Can be used as patient-spe-

cific therapy - lower risk of

rejection;

Reduced ethical issues. tumor formation.
Pluripotent origin - risk of tumor formation;

Additional risk profile due to the reprogramming process;

Difficult to standardize cell
product in a patient-specific
manner.
Difficult to standardize cell
product in a patient-specific manner.

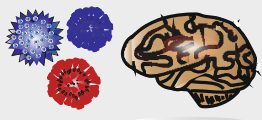

Directly reprogrammed cells

Reduced tumorigenic potential;

Patient-specific - lower risk of graft rejection;

Reduced ethical issues;

If reprogramming in vivo: much simpler process, where only virus are delivered into the brain.

Survival, long-term stability, maturation and function after transplantation remains unexplored;

Finite number of neurons can be produced - protocols' efficiency remains low;

Difficult to standardize cell product in a patient-specific manner;

A clinically suitable delivery method remains undevelopped for in vivo reprogramming techniques.

Fig. 1 Pros and Cons of different cell sources considered for cell replacement therapies

of a GABAergic IN fate, such as Ascll, Dlx5 and Lhx6, as well as genes expressed during early forebrain development such as FoxG1 and Sox 2 [57]. These GABAergic INs were transplanted into the mouse brain and showed to functionally integrate in the host neuronal networks, release GABA and inhibit the surrounding excitatory neurons in the hippocampus. A great part of the GABAergic neurons also showed PV protein and gene expression. Similarly, another group has used in vitro reprogramming to obtain subtype-specific INs only with the aid of one reprogramming factor Ascll, and upon treatment of the cultures with Forskolin, which were able to induce $80 \%$ of PV-expressing INs from mouse fibroblasts [58].

Directly reprogrammed neurons can, similarly to iPSCs, offer a cell-based and patient-specific source of neurons for disease modelling, while also involving much less ethical concerns compared to hESCs.

For cell repair strategies, reprogramming techniques can be used both for generating neurons in vitro that can then be used for transplantation $[42,47,50,56]$ or to reprogram resident glial cells of the brain into specific types of neurons in situ [59-62]. Thereby resident parenchymal cells could be converted into cell types that are lost due to disease by a process called in vivo reprogramming. This technique has also been used to reprogram cells in tissues other than the brain [63-65]. A more detailed overview of the current status of in vivo reprogramming in the central nervous system (CNS) will be done in the following sections.

\section{In vivo reprogramming}

In vivo reprogramming is still in its early stages but could develop into an option for cell therapy. To date, experiments involving this technique have been performed either by injecting reprogramming factors into the brain, which will then drive reprogramming of resident glia into neurons, or by transplanting cells that were transduced in vitro with reprogramming factors that can then be activated in vivo, post-transplantation. The first approach is thus far performed in mice resident glia and the latter, can involve the use of 
Table 1 A summary of published studies involving in vivo direct reprogramming of glial cells into neurons

\begin{tabular}{|c|c|c|c|c|c|c|c|}
\hline & Species & Starting cell & Factor combination & Vector system & Animal model & Resulting cell type & Region \\
\hline Buffo et al. [85] & Mouse & Proliferating glia & $\begin{array}{l}\text { Pax6/dominant } \\
\text { negative }\end{array}$ & RV & SW & Transient neurons & Cortex \\
\hline \multirow[t]{2}{*}{ Torper et al. [62] } & Rat & $\begin{array}{l}\text { Human astrocytes } \\
\text { and fibroblasts }\end{array}$ & $\begin{array}{l}\mathrm{ABM} \text { and } \\
\mathrm{ABM}+4 \mathrm{~F}\end{array}$ & Dox-inducible LVs & 6-OHDA & $\begin{array}{l}\text { Dopaminergic } \\
\text { neurons }\end{array}$ & Str and $\mathrm{Hpc}$ \\
\hline & Mouse & Resident astrocytes & $\mathrm{ABM}$ & Cre-inducible LVs & - & - & Str \\
\hline Niu et al. [69] & Mouse & Astrocytes & Sox 2 & $\begin{array}{l}\text { LVs/cell type spe- } \\
\text { cific promoter }\end{array}$ & $\begin{array}{l}\text { Young, adult and } \\
\text { aged mice }\end{array}$ & Neuroblasts & Str \\
\hline Grande et al. [59] & Rat & Proliferating cells & Ngn2 & RVs & $\mathrm{SW}$ and ischaemia & $\begin{array}{l}\text { GABAergic and } \\
\text { Glutamatergic } \\
\text { neurons }\end{array}$ & Str \\
\hline Su et al. [45] & Mouse & Astrocytes & Sox 2 & $\begin{array}{l}\text { LVs/cell type spe- } \\
\text { cific promoter }\end{array}$ & SCI & $\begin{array}{l}\text { Neuroblasts } \\
\quad \text { (GABAergic } \\
\text { interneurons and } \\
\text { glutamatergic } \\
\text { neurons, after } \\
\text { VPA) }\end{array}$ & Spinal cord \\
\hline Guo et al. [66] & Mouse & $\begin{array}{l}\text { Astrocytes and NG2 } \\
\text { glia }\end{array}$ & NeuroD1 & $\begin{array}{l}\text { RVs/cell type spe- } \\
\text { cific promoter }\end{array}$ & SW and AD model & $\begin{array}{l}\text { Glutamatergic } \\
\text { (Astrocyte- } \\
\text { derived), } \\
\text { Glutamatergic } \\
\text { and GABAergic } \\
\text { (NG2-derived) }\end{array}$ & Cortex \\
\hline $\begin{array}{l}\text { Magnusson et al. } \\
\text { [77] }\end{array}$ & Mouse & Astrocytes & $\begin{array}{l}\text { Block notch signal- } \\
\text { ling }\end{array}$ & $\begin{array}{l}\text { Transgenic mice/ } \\
\text { AAVs }\end{array}$ & Intact and stroke & Neurons & Str \\
\hline Heinrich et al. [100] & Mouse & NG2 glia & Sox 2 & RVs & SW & Neurons & Cortex \\
\hline Niu et al. [98] & Mouse & Astrocytes & Sox 2 & $\begin{array}{l}\text { LVs/cell type spe- } \\
\text { cific promoter }\end{array}$ & - & $\begin{array}{l}\text { Neural progeni- } \\
\text { tors (Calretinin+ } \\
\text { interneurons, } \\
\text { after VPA) }\end{array}$ & Str \\
\hline Torper et al. [67] & Mouse & $\begin{array}{l}\text { Astrocytes and NG2 } \\
\text { glia }\end{array}$ & ALN & $\begin{array}{l}\text { Cre-inducible } \\
\text { AAVs }\end{array}$ & - & $\begin{array}{l}\text { GABAergic and } \\
\text { Glutamatergic } \\
\text { neurons }\end{array}$ & Str \\
\hline Liu et al. [60] & Mouse & Astrocytes & Ascl1 & $\begin{array}{l}\text { AAVs/cell type spe- } \\
\text { cific promoter }\end{array}$ & - & $\begin{array}{l}\text { GABAergic and } \\
\text { Glutamatergic } \\
\text { neurons }\end{array}$ & $\begin{array}{c}\text { Dorsal midbrain, } \\
\text { Str and cortex }\end{array}$ \\
\hline $\begin{array}{l}\text { Di Val Cervo et al. } \\
\text { [71] }\end{array}$ & Mouse & Astrocytes & NeAL218 & $\begin{array}{l}\text { Tet-regulated LVs/ } \\
\text { GFAP-tTA mice }\end{array}$ & 6-OHDA & $\mathrm{TH}+$ neurons & Str \\
\hline Weinberg et al. [70] & Rat & Oligodendrocytes & $\begin{array}{l}\text { PTB inhibitor/ } \\
\text { miRNA }\end{array}$ & $\begin{array}{l}\text { Oligodendrocyte- } \\
\text { specific AAVs }\end{array}$ & - & Striatal neurons & Str \\
\hline Brulet et al. [99] & Mouse & $\begin{array}{l}\text { Non-reactive astro- } \\
\text { cytes }\end{array}$ & NeuroD1 & $\begin{array}{l}\text { Systemic injection/ } \\
\text { AAV9 }\end{array}$ & - & - & Str and cortex \\
\hline Pereira et al. [61] & Mouse & NG2 glia & $\begin{array}{l}\text { ALN, NgLN, } \\
\text { ANgN, NgND1 } \\
\text { AFLE }\end{array}$ & $\begin{array}{l}\text { Cre-inducible } \\
\text { AAVs }\end{array}$ & Intact vs 6-OHDA & $\begin{array}{r}\text { Parvalbumin+ } \\
\text { interneurons }\end{array}$ & Midbrain and Str \\
\hline Niu et al. [68] & Mouse & Striatal MSNs & $\begin{array}{l}\text { Sox2, Nurr1, } \\
\text { Lmx1A, FoxA2, } \\
\text { Valproic acid }\end{array}$ & $\begin{array}{l}\text { LVs/cell type } \\
\text { specific promoter } \\
\text { or hPGK }\end{array}$ & - & TH+ neurons & Str \\
\hline Matsuda et al. [83] & Mouse & Microglia & NeuroD1 & $\begin{array}{l}\text { LVs/cell type spe- } \\
\text { cific promoter }\end{array}$ & - & $\begin{array}{l}\text { DARPP32+ } \\
\text { striatal projection } \\
\text { neurons }\end{array}$ & Str \\
\hline
\end{tabular}

$A B M$ Ascl1, Brn2, Myt1L, $A B M+2 F \mathrm{ABM}+\mathrm{Lmx1a}, \mathrm{Lmx} 1 \mathrm{~b}, A B M+4 F \mathrm{ABM}+\mathrm{Lmx} 1 \mathrm{a}, \mathrm{Lmx} 1 \mathrm{~b}$, FoxA2, Otx2, NeAL218 NeuroD1, Ascl1, Lmx1a, miRNA218, ALN Ascl1, Lmx1a, Nurr1, NgLN Neurogenin2, Lmxla, Nurr1, ANgN Ascl1, Neurogenin2, Nurr1, NgND1 Neurogenin2, Nurr1, NeuroD1, AFLE Ascl1, FoxA2, Lmxla, En1, LV lentivirus, RV retrovirus; AAV adeno-associated virus; $S C$ spinal cord, SCI spinal cord injury, $S W$ stab-wound, Str striatum, $H p c$ hippocampus, MSNs medium-spiny neurons

human cells transplanted to the rodent brain. A large number of reports indicating the feasibility of this technique have been published, and results indicate that different types of neurons can be generated in vivo. The large majority of obtained neurons are either GABAergic or Glutamatergic
[45, 59, 60, 66, 67], but also other subtype-specific neurons have been generated such as DA neurons $[67,68]$ or INs [61, 69] (see Table 1). Thus far, in vivo neuronal reprogramming has been established in different regions of the brain such as the cortex, spinal cord, striatum and the midbrain $[45,61$, 
70]. Moreover, the reprogramming can take place both in the intact and in lesioned CNS $[45,59,61,71]$ showing its potential for application in a clinical context.

To fully understand the process and its limitations, aspects such as (1) the cell of origin, (2) genes used for reprogramming, (3) chosen delivery systems, and (4) the region where reprogramming occurs and what effect this might have on functionality, need to be explored. In the following sections, a discussion on these aspects as well as an overview on the existing in vivo studies where subtypespecific neurons were generated will be made.

\section{Cell of origin}

The first important aspect to consider for in vivo reprogramming studies is the identification of the cell type that is most suited to undergo conversion into the desired cell type, and that is available at the right place. It has been hypothesised that the selection of the source cell type will impose a specific molecular context, defined by its gene expression profile and epigenetic signature, in which reprogramming factors will have to operate [72]. Based on this, different resident cell types of the brain have been considered for in vivo reprogramming, including glial cells such as astrocytes and oligodendrocyte precursor cells, also known as NG2 glia. These cells play multiple roles in helping to alleviate neurological defects after brain injury, by promoting axonal and neuronal function and thereby fostering neuronal survival [73]. Astrocytes could be advantageous to use for cell reprogramming in vivo due to their ubiquitous distribution throughout the CNS in large amounts and the fact that they are associated with a high plasticity [74]. A recent paper points to a heterogenous susceptibility for reprogramming by astrocytes derived from different parts of the brain [75]. Furthermore it has been demonstrated that astrocytes can be triggered into a tripotent differentiating and self-renewing state after an injury, which could potentially create the appropriate context for reprogramming into neurons [76]. Remarkably, recent data demonstrate that astrocytes seem to entail a latent neurogenic program that can be initiated upon injury [77]. The fact that striatal astrocytes are able to produce neuroblasts in models of Stroke or Huntington's disease sheds new light on the neurogenic potential of the adult brain and raises questions on whether we can promote renewal of striatal neurons for therapeutic approaches. Further debate on adult neurogenesis has been supported by a recent paper that demonstrates persistence in neurogenesis during both physiological and pathological aging in humans [78] and this in turn points to a potentially relevant mechanism underlying Alzheimer's disease symptoms.

The extensive self-renewal capability of NG2 glia [79] also makes them interesting candidates for in vivo reprogramming, as the potential risks in disturbing homeostasis can be avoided. In addition, NG2 glia receives direct input from neurons [80], so the necessary machinery to form postsynaptic compartments is already in place, potentially facilitating the synaptic integration of reprogrammed, NG2derived neurons. Also, these glial cells may hold the key to overcome another major problem faced in attempts to replace degenerated neurons, namely, the long-term survival of the newly regenerated neurons [73].

Besides astrocytes and NG2-glia, other cells have been implicated for reprogramming such as specific sets of pericytes, a cell type that lines the inside of capillaries in the CNS [81] or microglial cells that have the ability to migrate to the lesion site. The migration of monocyte-derived macrophages to the lesion area from blood [82] has attracted attention due to the potential as therapeutic delivery strategy for reprogramming factors. For this, monocytes could be genetically modified to express inducible reprogramming factors and administered by systemic injection into the subject, being reprogrammed into neurons when reaching the CNS. In a recent publication, the feasibility of microgliato-neuron in vivo reprograming in the striatum of the adult mouse has been demonstrated through the overexpression of a single transcription factor [83].

Upon neurodegeneration or brain injury, glial cells undergo important morphological, functional and molecular changes, which initially promote tissue repair, but later can contribute to adverse effects for neuronal survival as well as neurite and synapse formation. A specific and timed reprogramming of these cells into neurons could provide a new therapeutic approach for brain repair. Ideally, one would want to selectively convert scar-forming glial cells into neurons, while avoiding an effect on the populations of glia that are crucial for effective wound healing processes [84]. Other cell sources involved in glial scar formation also possess some potential for in vivo reprogramming. By forcing the reactive glial cells to express specific TFs such as Pax6 together with a dominant negative form of Olig2, Buffo et al. showed that transient immature neurons can be formed in the mouse brain after a stab-wound-induced cortical brain injury [85].

Taken together, new insights into glial cell diversity have opened new avenues towards best utilizing the CNSresident cells for repair purposes. Yet, much still remains to be understood about this diversity to be putting it at its best use.

In contrast to glial cells that can become reactive and proliferate under certain conditions, post-mitotic neurons do not normally change their identity for the lifespan of the organism, especially not during adulthood. Nevertheless, a recent paper identified striatal neurons as the cell source for neuronal reprogramming in the adult mouse brain [68]. In this paper, in vivo reprogramming was promoted in the striatum by the transcription factors Sox2, Nurrl, Lmxla, and 
FoxA2 along with the chemical factor valproic acid. Immunohistochemistry and genetic lineage tracing revealed that in the origin of induced DA neurons were the striatal neurons. This data indicates that neurons can be redirected to other phenotypes also in the adult brain.

\section{Reprogramming process, genes, and delivery}

It is still largely undefined how an individual cell transits from its original identity to a neuronal fate during cellular reprogramming. Even so, recently developed techniques are now unravelling this process bit-by-bit. By analysing transcriptomes of cell populations and single cells at different time points after viral transduction, two studies have contributed importantly to the field by showing that the process of direct reprogramming might involve an immature intermediate state and is not purely a transition between fully differentiated stages [86, 87]. Overexpression of the proneuronal pioneer factor Ascll in mouse embryonic fibroblasts led to two gene regulatory events during reprogramming starting with an initiation stage where the cells exit the cell cycle and cytoskeletal reorganization, followed by a maturation stage, where genes involved in synaptic maturation are turned on [87]. Human brain pericytes have been shown to transiently express neural stem cell-like genes and then to enter a bifurcation in lineage differentiation into distinct excitatory or inhibitory pathways [86]. Interestingly the two groups of starting populations described in this publication, differed markedly in their response to the reprogramming genes Ascll and Sox2, demonstrating that the reprogramming success critically depends on cellular context [86].

That might explain why several factors that have been shown to convert astrocytes into neurons in vitro [88, 89], yet fail to do so in vivo [59]. Some of the genes that have been effective at reprogramming somatic cells into DA neurons in vitro, give rise to INs instead when used for in situ reprogramming of resident glia in the striatum [61]. The fact that in vivo reprogramming studies have not yet convincingly and reproducibly shown the generation of a DA neuronal subtype in vivo, raises the question of whether the activation cascades necessary for the formation of DA cells in situ are somehow dependent of the ones involved in the formation of INs, or whether the IN subtype is the default subtype formed when these genes are introduced in the brain. These different outcomes could also reflect differences between cellular identity of resident glial populations and the starting population in the in vitro studies.

It has been accepted in the field of cellular reprogramming that genes that are important during development in the formation and specification of a specific neuronal subtype, often are effective at reprogramming an adult somatic cell into that neuronal subtype as well [90]. Hence, understanding how these processes work is of great importance and provides valuable information for reprogramming studies. As an example and in support of this, many of the genes identified during midbrain DA neuron formation in vivo have already been used to reprogram somatic cells into induced DA neurons in vitro [42, 44, 60, 91-93].

GABAergic IN fates arise from an important interplay of genes, expressed in early progenitor stages. Genes like Ascll, Dlx 5 and $L h x 6$ are considered inducers of a GABAergic IN fate [94-97]. It has been shown that these genes, together with Sox2 and FoxG1, are able to induce an IN fate when fibroblasts are transduced in vitro, and that Ascll, $D l x 5$, and Lhx6 have a more direct cooperation in activating the molecular machinery responsible for GABAergic specification [57]. In support of this hypothesis, the authors of this study have shown that silencing of either FoxGl or Sox 2 is sufficient to block, in a cell-autonomous manner, the ability of Ascll to induce a GABAergic neuronal fate in cortical progenitor cells. In two separate studies, Sox2 has been shown to be sufficient to reprogram astrocytes into INs in the mouse CNS [45, 98] (see Table 1).

When performing in vivo reprogramming in the brain, one needs to account for the correct targeting of specific cell populations. Viral vectors are commonly used to deliver genetic material into the brain cells. To target proliferating cells, retroviral vectors (RVs) can be used since these vectors specifically target dividing cells $[59,66]$. Alternatively, lentivirus (LVs) and adeno-associated (AAV) vectors can be used, and these have the advantage of infecting both dividing and non-dividing cells of the brain [59, 66, 99]. To target specific cell populations in the brain, subtype-specific promoters are used for the reprogramming genes in viral constructs [66, 98].

Cre-inducible LV or AAV vectors have been used to reprogram resident glial cells into neurons in the mouse brain, and using a neuron-specific synapsin-driven FLEX reporter, overexpressed in these in vivo reprogrammed neurons, the number of newly formed mature neurons with a glial origin could be easily determined, providing for an immediate method to identify and characterize those neurons [61, 67]. On the other hand, with these viruses it remains difficult to determine the exact number of targeted cells in vivo as only the converted cells are identified. Other viral systems, e.g. encoding a fluorescent reporter that is not expressed under neuron-specific promoter works better for identification and quantification of transduced cells $[100,48]$.

Finding an appropriate and safe system for gene delivery in humans is also under consideration in the field. Certain serotypes of AAVs have been reported to successfully cross the blood-brain barrier, opening up the possibility to transduce cells in the brain through systemic injection (reviewed in [84]). This could avoid secondary damage due to invasive cerebral injections, and allow transductions 
in larger areas, required in later stages of neurodegenerative diseases.

\section{Region/subtype and functionality}

For in vivo reprogramming to become an attractive possibility for future brain repair, we need to control the subtype identity and functionality of the generated neurons more effectively. Indeed for in vivo reprogramming, environmental regional differences have been observed in several parts of the brain. While the transcription factor Ngn2 alone can generate GABAergic neurons in the striatum, the same factor induced glutamatergic cells in the neocortex [59] (see Table 1). Besides, brain insults seem to differentially modulate the generation of new neurons in vivo $[59,100]$.

It is important to assess the final outcome of direct reprogramming in terms of function and connectivity of reprogrammed cells in the adult brain. The formation of synapses and neuronal function, with ability to electrically communicate, is necessary for a neuron to exert any behavioural effect including attenuating the disease symptoms [101]. The first evidence that reprogrammed neurons functionally mature in the brain was provided by [66]. Patch-clamp electrophysiological recordings (see Fig. 2, [102-105]) of cortical tissue slices revealed a capability of both evoked and spontaneous action potentials for the new neurons obtained in NeuroDl-reprogrammed astrocytes around 4 weeks after transduction. Another group used Sox2 to reprogram NG2 glia into neuroblasts, which further matured into neurons, capable of firing action potentials and exhibiting post-synaptic currents in vivo [100].

NG2-glia-derived reprogrammed neurons in the intact striatum have been further studied using the same technique, to demonstrate a gradual maturation in function with capacity for evoked repetitive action potentials and post-synaptic currents from 5 to 12 weeks after virus injection [61]. It was here shown that the functional properties of the reprogrammed neurons correlated to maturation over time, and by 12 weeks after viral injection, the reprogrammed cells show molecular and functional properties of endogenous striatal neurons. Moreover, the membrane-related intrinsic properties also indicated a gradual maturation, i.e., membrane capacitance increased, while the membrane resistance decreased, and the restingmembrane potential became more hyperpolarized (see Fig. 2). Neurons reprogrammed from NG2-glia further received synaptic input from local host neurons as shown by monosynaptic tracing [67] (Fig. 2).

\section{In vivo reprogramming into subtype-specific neurons}

After the first evidence that in vivo neuronal reprogramming of resident glial cells could occur in situ [85], research groups further explored this approach with the aim of using it for CNS repair. Torper et al. introduced factors in resident striatal astrocytes that were shown to reprogram somatic cells into DA neurons in vitro (Ascll, Brn2 and MytlL [41]), and stably converted these into NeuN-expressing neurons in the adult mouse brain [62]. In the same year, another group reported that LV-mediated overexpression of Sox2, driven by a GFAP-specific promoter could reprogram adult striatal astrocytes into neuroblasts that could later form neurons upon exposure to noggin and BDNF, or upon treatment with a histone deacetylase inhibitor [69]. Further reports over the years have shown reprogramming of different cell types $[59,66,98,100]$ into neuroblasts or neurons in vivo, in different regions of the brain and spinal cord [45, 60], through the use of distinct factor combinations and delivery methods [67, 100] (see Table 1). Among these, two studies have shown the generation of DA neurons in the striatum of intact or lesioned brains targeting either glia [71] or striatal neurons [68].

Recently, even the epigenetic changes that occur during reprogramming have been described as the underlying mechanism during transdifferentiation [106, 107]. Matsuda and co-authors have been pioneers exploring in detail the epigenetic regulation of the neuronal factor NeuroDl on the in vivo reprogrammed neurons from microglia. The authors point to a global epigenetic remodelling done by NeuroD1, starting with an initial onset of a neuronal program and consecutive downregulation of microglial genes [83].

Thus far, functional assessment and protein or gene expression have been sparse and the different neuronal subtypes generated in the animal brain have mainly been characterised as either GABAergic or Glutamatergic [59, 67]. Our lab has been one of the few that further evaluated the subtype-specificity of in vivo reprogrammed neurons. Using genome analysis, protein-expression and electrophysiology, we could characterize the reprogrammed neurons in the striatum and conclude that a big portion of the neurons (40\%) showed properties similar to fast-spiking GABAergic INs expressing PV [61], a cell type that usually accounts only for $1 \%$ of all striatal neurons and that plays a highly interesting role in striatal function. A minority of the neurons expressed markers and showed functionality traits similar to other types of striatal INs, whereas very few cells showed properties of neurons more abundantly found in the striatum like medium-spiny neurons [61]. GABAergic INs have previously been generated in vivo both in the latent state and after a trauma such as excitotoxic lesion [108] or stroke (without addition of any reprogramming factors) or with 


\section{Measurement of function and connectivity of in vivo reprogrammed neurons}

\section{Electrophysiology}

Reprogrammed neurons can be visualized in tissue slices (e.g. using neuron-specific fluorescence) and patched for wholecell electrophysiology. With this method the following measurements can be assessed:

Excitatory and inhibitory postsynaptic potential or current (EPSP or IPSP), indicating functional post-synaptic contacts.

Current-induced action potentials, a protocol forcing the cell to depolarize with step-wise increases of current to induce action potential that indicates neuronal function. Different populations of neurons show distinct firing pattern (due to specific neuronal morphology, presence of certain membrane receptors etc).

Intrinsic membrane properties i.e. membrane resistance, membrane capacitance and resting membrane potential that indicate a neuronal phenotype and maturation. As a neuron mature its membrane capacitance increases (due to an increased size of the cell) whereas its membrane resistance decreases (due to increased density of ion channels). As a neuron functionally matures, its resting membrane potential gradually hyperpolarizes (due to changed membrane permeability).

Long-term plasticity (LTP or LTD), persistent changes in synaptic strength that occur in response to incrase or decrease in the synaptic activity. This is considered the underlying mechanism for brain circuit plasticity and learning. Molecular mechanisms involve NMDA and AMPA glutamate receptors as well as postsynaptic calcium entry.

Both Optogenetic [102] and Chemogenetic [103] techniques can be coupled to whole-cell patch clamp and allow for cellspecific activation.

\section{Behavioral assessments}

The ultimate goal for restorative cell therapies is to restore or at least attenuate the deficiencies in behavior or cognition. Some of these aspects can be assessed in behavioral tests in animal models of neurological diseases. Transplanted INs from fetal derived tissue or ESC have shown to attenuate the deficits in e.g. schizophrenia-like symptoms, cognitive deficits, epileptic seizures or PD related motor-deficits (reviewed in [104]). While these findings demonstrate the pro-cognitive effects of IN-based strategies the question remains if IN generated from reprogrammed neurons could do the same.

\section{Synaptic tracing technologies using modified rabies viruses}

In order to trace the reprogrammed neurons and their pre- or postsynaptic connections in the animal brain, modified rabies virus-based tracing methodology can be used. This allows mapping of the 3D circuitry integration into local and distal brain regions and shows that the newly reprogrammed neurons are integrated into host brain [105]. 3D imaging of solvent-cleared organs (iDISCO) technique can be used post-mortem to assess the regional distribution, connection and rough morphology of the reprogrammed neurons.

\section{Electron Microscopy}

Electron Microscopy (EM) can be used to assess the detailed ultrastructure of reprogrammed neurons with their cell soma, protrusions and synaptic connections to the surrounding neurons. EM uses accelerated electrons as source of illumination that allows a higher resolution for the picture compared to ordinary light microscopes.

\section{Electrochemistry}

The reprogrammed cells can be assessed for their neurotransmitter release using amperometry either in the animal brain or in tissue slices. Unlike patch clamp techniques, the electrode for amperometry is not inserted into or attached to the cell, but brought in close proximity of the cell. The measurements from the electrode originate from an oxidizing reaction of a vesicle cargo released into the medium.

Fig. 2 Methods for functional assessment of reprogrammed neurons 
Notch signalling inhibition [77] or with Sox2 induction [45, 98]. The studies from Su et al. and Niu et al. 2015 have further showed neuronal reprogramming into GABAergic INs in the spinal cord and striatum; however, under different conditions and with unreported proportion of cells (see Table 1). In Niu et al. 2015, the reprogrammed astrocytes in the striatum showed properties of calretinin INs [98], whereas $\mathrm{Su}$ et al. 2014 reprogrammed astrocytes into GAD65-expressing INs in the spinal cord [45].

\section{Interneurons: the re-shapers of neural networks}

INs have an essential role in balancing and coordinating different networks in the nervous system [109]. In fact, INs populate the spinal cord and the brain, both cortically and subcortically, with a great variability in cell types. The identification of different types of INs done so far is based on different aspects: firing properties, immunohistochemical profile and gene expression. For the striatal INs, the electrophysiological profile allows distinguishing between the following groups: fast-spiking INs (FSI), characterised by low input resistance and a fast firing pattern; low threshold INs (LTI), represented by a high input resistance and a sustained plateau potential present after current injections; and tonic active cholinergic INs (TANs), which have an hyperpolarization-activated current and long spike afterhyperpolarizations [110]. Another criterion used to classify the IN populations is their immunohistochemical profile, as they can express PV, SST, neuropeptide Y (NPY), nitric oxide synthase (NOS), and calretinin [110, 111]. GABAergic INs besides GABA, express the $\mathrm{Ca}^{2+}$-binding protein $\mathrm{PV}$, the neuropeptide SST, and the ionotropic serotonin receptor (5HT3a), (reviewed in [112-114]) whereas excitatory INs express gastrin-releasing peptide or substance $\mathrm{P}$ [115]. Although different INs are found in distinct parts of the brain, the identification of the exact type of IN is not always easy to make. More knowledge about the existing subtypes would be important as it could bring and possibly influence future therapeutic approaches [116].

INs work as a buffer system of the excitatory signals avoiding runaway excitation [117]. This role is in line with their sparse localisation amongst other cells [118] and their lack of major distant projections [119] for the majority of INs [117]. INs function not merely as guards of excitatory networks with feed-back inhibition, but they also contribute to the general activity with motif-like feed-forward inhibition which allows activity signal synchronisation and long-term alteration of cellular excitability [120]. Another characteristic of INs is represented by their ability for electrical coupling between different regions of the brain that allows the regulation of chemical synapse development and circuits' formation in the neocortex [121-123]. In addition to principal cells, neocortical GABAergic INs are also known to target other INs, giving rise to disinhibitory effect that is found in different regions of the brain [124, 125]. At last, INs can drive cortical plasticity and contribute to the reshaping of neural networks $[126,127]$. In this sense, they are paramount in balancing excitatory and inhibitory signalling, a balance that when disturbed is correlated to several neurological conditions and psychiatric disorders such as autism, schizophrenia, and intellectual disabilities [128].

\section{Interneuron dysfunction in psychiatric disorders and cell reprogramming}

Interneuropathies constitute a wide range of neurological disorders that directly result from IN dysfunctions [129]. Whether they are caused by a reduction in IN number or more specific deficits in the firing properties of individual neurons, these syndromes all share impaired GABAergic transmission [104]. As GABAergic INs are the main cellular elements in controlling excitability in the brain, severe GABAergic deficits can cause a pathological hyperexcitability. In line with this, many of the genes that are linked to epilepsy are involved in the regulation of IN development and function. Recent data also point to that subtle perturbations in the excitatory-inhibitory balance existing in other psychiatric conditions and neurological disorders [128] such as Alzheimer's disease [130], chronic pain, dystonia [131], PD, schizophrenia and anxiety (reviewed in [5]). For example, several models of schizophrenia have shown an alteration in the population of PV-expressing INs, with changes in their number and positioning [132]. In autism, a reduced number of PV-expressing INs have been reported, along with a reduced mRNA level of GAD67 and the GABA membrane transporter 1 (GAT1) [133]. Reduced striatal PV expression has further been shown in a dystonia animal model where a delayed IN maturation was speculated to be involved in the pathophysiology [131]. There are also disturbances in biochemical markers in the PV INs such as voltage-gated potassium or sodium channels that have been associated to schizophrenia or AD [130, 134]. The selective reduction in neuronal activity of the PV INs is hypothesised to lead to an attenuation of gamma oscillations that underlie autism, schizophrenia and other diseases $[135,136]$. A feature that is common to a broad spectrum of neuropsychiatric disorders is repetitive behaviours such as the ones featured in Tourette's syndrome. Here, compelling evidence implicates a decrease in striatal PV INs in the emergence of repetitive behaviour both in animal models [137] and in patients [138, 139]. In a DAT-overexpressing rat model that displays behavioural abnormalities, the repetitive behaviour has been linked to decreased number of striatal PV INs and increased c-fos 
levels in cortical areas [140]. Among other animal models, the mutant mouse Disrupted-in schizophrenia 1 (human full length DISC1 overexpression) gene has shown to lead to neurodevelopmental changes consistent with the proposed neurodevelopmental origin of schizophrenia, i.e., reduction of PV INs in cortex and striatum and impaired migration of INs from ganglionic eminence [141, 142].

\section{Future prospects and conclusions}

Given the involvement of INs in neuropsychiatric and other neurological diseases, the question that naturally occurs is whether we could attenuate any of the neurological or psychiatric symptoms by replacing INs. Recent studies suggest the possibility of tackling several of the above-mentioned diseases with transplants of INs derived from fetal tissue or MGE to the spinal cord to treat SCI, to the striatum for PD, hippocampus for epilepsy and cerebral cortex for psychiatric diseases [5, 66, 104]. Yet, IN replacement for these diseases has largely been neglected in preclinical research. To move this research forward, it is imperative to develop tools and technologies that address the most urgent questions relating to the therapeutic potency of INs, such as their genetic profile and electrophysiological maturation, and synaptic connectivity in the brain (see Fig. 2). Moreover, it is imperative to generate subtype-specific neurons that are matching their endogenous counterparts and to transplant or in vivo reprogram these in the correct target brain region. The ability to generate subtype-specific INs via cell reprogramming opens up for new and safer sources of clinically relevant neurons in the future, as the novel cells are not formed via a proliferative cell intermediate. Notably, this direct reprogramming process is potentially much faster than generating iPSCs or differentiating ESCs into the target cell types, which could take months. Moreover, while iPSCs do not retain their agerelated signatures, the directly reprogrammed neurons still display their age-related transcriptional profiles and associated nuclear transport [143]. This allows us to model ageassociated processes in vitro, an aspect that is particularly valuable when studying neurodegenerative diseases. In line with this, reprogrammed cells could provide an in vitro platform for drug discovery, toxicology studies and gene therapy testing. Using this approach, it has been shown that overexpression of a gene linked to schizophrenia and bipolar disorder in reprogrammed GABAergic neurons, led to reduced inhibitory synaptic transmission [144].

Expandable cell sources like embryonic stem cells, neural stem cells and more recently described iPSCs, are all under investigation for brain repair. Even though recent progress has been made in differentiating pluripotent stem cells into the appropriate neuronal subtype, fetal transplants are still the gold standard as these are the best specified to differentiate into the appropriate type of neurons. Nevertheless, attempts to use endogenous cell sources are very attractive as they would eliminate the dependence of an exogenous cell source, removing ethical concerns in terms of donor cell origin, difficulties in meeting GMP requirements and logistical issues that are associated with extrinsic cell sources. Therefore, it could be worth improving and developing in vivo reprogramming technique, e.g. by defining the most appropriate cells to target or to define what region-specific features are present in the environment where reprogramming occurs, and how they may affect the final cell identity, functionality and integration. Furthermore, to expect functional recovery, the reprogrammed neurons have to integrate and function as their endogenous counterparts. The most important task though, remains to generate an adequate number of subtype-specific neurons into the brain that can restore network alterations in a specific disease. There are still challenges to achieve these goals but the ability to generate subtype-specific neurons via in vivo reprogramming could open up for new and safer sources of clinically relevant neurons in the future.

Acknowledgements Marcella Birtele has been funded by European Union Horizon 2020 Program (H2020-MSCA-ITN-2015) under the Marie Skłodowska-Curie Innovative Training Networks and Grant Agreement No. 676408. Daniella Ottosson funded by Swedish Research Council. We thank Olof Landelius Torper and Malin Parmar for their constructive feedback during the elaboration of this review.

Open Access This article is distributed under the terms of the Creative Commons Attribution 4.0 International License (http://creativeco mmons.org/licenses/by/4.0/), which permits unrestricted use, distribution, and reproduction in any medium, provided you give appropriate credit to the original author(s) and the source, provide a link to the Creative Commons license, and indicate if changes were made.

\section{References}

1. Lindvall O, Rehncrona S, Gustavii B, Brundin P, Astedt B, Widner H, Lindholm T, Bjorklund A, Leenders KL, Rothwell JC, Frackowiak R, Marsden CD, Johnels B, Steg G, Freedman R, Hoffer BJ, Seiger L, Stromberg I, Bygdeman M, Olson L (1988) Fetal dopamine-rich mesencephalic grafts in Parkinson's disease. Lancet 2:1483-1484

2. Lindvall O, Brundin P, Widner H, Rehncrona S, Gustavii B, Frackowiak R, Leenders KL, Sawle G, Rothwell JC, Marsden CD et al (1990) Grafts of fetal dopamine neurons survive and improve motor function in Parkinson's disease. Science 247:574-577

3. Lindvall O, Bjorklund A (2004) Cell therapy in Parkinson's disease. NeuroRx 1:382-393. https://doi.org/10.1602/neuro rx.1.4.382

4. Bachoud-Levi AC, Remy P, Nguyen JP, Brugieres P, Lefaucheur JP, Bourdet C, Baudic S, Gaura V, Maison P, Haddad B, Boisse MF, Grandmougin T, Jeny R, Bartolomeo P, Dalla Barba G, Degos JD, Lisovoski F, Ergis AM, Pailhous E, Cesaro P, Hantraye P, Peschanski M (2000) Motor and cognitive improvements 
in patients with Huntington's disease after neural transplantation. Lancet 356:1975-1979

5. Southwell DG, Nicholas CR, Basbaum AI, Stryker MP, Kriegstein AR, Rubenstein JL, Alvarez-Buylla A (2014) Interneurons from embryonic development to cell-based therapy. Science 344:1240622. https://doi.org/10.1126/science.1240622

6. Gage FH (2012) Transplantation in the future. Prog Brain Res 200:7-13. https://doi.org/10.1016/b978-0-444-59575-1.00001-6

7. Alvarez Dolado M, Broccoli V (2011) GABAergic neuronal precursor grafting: implications in brain regeneration and plasticity. Neural Plast 2011:384216. https://doi. org/10.1155/2011/384216

8. Thomson JA, Itskovitz-Eldor J, Shapiro SS, Waknitz MA, Swiergiel JJ, Marshall VS, Jones JM (1998) Embryonic stem cell lines derived from human blastocysts. Science 282:1145-1147

9. Kriks S, Shim JW, Piao J, Ganat YM, Wakeman DR, Xie Z, Carrillo-Reid L, Auyeung G, Antonacci C, Buch A, Yang L, Beal MF, Surmeier DJ, Kordower JH, Tabar V, Studer L (2011) Dopamine neurons derived from human ES cells efficiently engraft in animal models of Parkinson's disease. Nature 480:547-551. https ://doi.org/10.1038/nature10648

10. Perrier AL, Tabar V, Barberi T, Rubio ME, Bruses J, Topf N, Harrison NL, Studer L (2004) Derivation of midbrain dopamine neurons from human embryonic stem cells. Proc Natl Acad Sci USA 101:12543-12548. https://doi.org/10.1073/pnas.04047 00101

11. Gaspard N, Bouschet T, Hourez R, Dimidschstein J, Naeije G, van den Ameele J, Espuny-Camacho I, Herpoel A, Passante L, Schiffmann SN, Gaillard A, Vanderhaeghen P (2008) An intrinsic mechanism of corticogenesis from embryonic stem cells. Nature 455:351-357. https://doi.org/10.1038/nature07287

12. Eiraku M, Watanabe K, Matsuo-Takasaki M, Kawada M, Yonemura S, Matsumura M, Wataya T, Nishiyama A, Muguruma K, Sasai Y (2008) Self-organized formation of polarized cortical tissues from ESCs and its active manipulation by extrinsic signals. Cell Stem Cell 3:519-532. https://doi.org/10.1016/j. stem.2008.09.002

13. Barberi T, Klivenyi P, Calingasan NY, Lee H, Kawamata $H$, Loonam K, Perrier AL, Bruses J, Rubio ME, Topf N, Tabar V, Harrison NL, Beal MF, Moore MA, Studer L (2003) Neural subtype specification of fertilization and nuclear transfer embryonic stem cells and application in parkinsonian mice. Nat Biotechnol 21:1200-1207. https://doi.org/10.1038/nbt870

14. Li XJ, Du ZW, Zarnowska ED, Pankratz M, Hansen LO, Pearce RA, Zhang SC (2005) Specification of motoneurons from human embryonic stem cells. Nat Biotechnol 23:215-221. https://doi. org/10.1038/nbt1063

15. Shin S, Dalton S, Stice SL (2005) Human motor neuron differentiation from human embryonic stem cells. Stem Cells Dev 14:266-269. https://doi.org/10.1089/scd.2005.14.266

16. Pomp O, Brokhman I, Ben-Dor I, Reubinoff B, Goldstein RS (2005) Generation of peripheral sensory and sympathetic neurons and neural crest cells from human embryonic stem cells. Stem Cells 23:923-930. https://doi.org/10.1634/stemcells.2005-0038

17. Lee G, Kim H, Elkabetz Y, Al Shamy G, Panagiotakos G, Barberi T, Tabar V, Studer L (2007) Isolation and directed differentiation of neural crest stem cells derived from human embryonic stem cells. Nat Biotechnol 25:1468-1475. https://doi.org/10.1038/ nbt 1365

18. Elkabetz Y, Panagiotakos G, Al Shamy G, Socci ND, Tabar V, Studer L (2008) Human ES cell-derived neural rosettes reveal a functionally distinct early neural stem cell stage. Genes Dev 22:152-165. https://doi.org/10.1101/gad.1616208

19. Shin S, Mitalipova M, Noggle S, Tibbitts D, Venable A, Rao R, Stice SL (2006) Long-term proliferation of human embryonic stem cell-derived neuroepithelial cells using defined adherent culture conditions. Stem Cells 24:125-138. https://doi. org/10.1634/stemcells.2004-0150

20. Maroof AM, Keros S, Tyson JA, Ying SW, Ganat YM, Merkle FT, Liu B, Goulburn A, Stanley EG, Elefanty AG, Widmer HR, Eggan K, Goldstein PA, Anderson SA, Studer L (2013) Directed differentiation and functional maturation of cortical interneurons from human embryonic stem cells. Cell Stem Cell 12:559-572. https://doi.org/10.1016/j.stem.2013.04.008

21. Nicholas CR, Chen J, Tang Y, Southwell DG, Chalmers N, Vogt D, Arnold CM, Chen YJ, Stanley EG, Elefanty AG, Sasai Y, Alvarez-Buylla A, Rubenstein JL, Kriegstein AR (2013) Functional maturation of hPSC-derived forebrain interneurons requires an extended timeline and mimics human neural development. Cell Stem Cell 12:573-586. https://doi.org/10.1016/j. stem.2013.04.005

22. Liu Y, Liu H, Sauvey C, Yao L, Zarnowska ED, Zhang SC (2013) Directed differentiation of forebrain GABA interneurons from human pluripotent stem cells. Nat Protoc 8:1670-1679. https:// doi.org/10.1038/nprot.2013.106

23. Butt SJ, Stacey JA, Teramoto Y, Vagnoni C (2017) A role for GABAergic interneuron diversity in circuit development and plasticity of the neonatal cerebral cortex. Curr Opin Neurobiol 43:149-155. https://doi.org/10.1016/j.conb.2017.03.011

24. Tyson JA, Goldberg EM, Maroof AM, Xu Q, Petros TJ, Anderson SA (2015) Duration of culture and sonic hedgehog signaling differentially specify PV versus SST cortical interneuron fates from embryonic stem cells. Development 142:1267-1278. https://doi. org/10.1242/dev.111526

25. Grealish S, Drouin-Ouellet J, Parmar M (2016) Brain repair and reprogramming: the route to clinical translation. J Intern Med 280:265-275. https://doi.org/10.1111/joim.12475

26. Steinbeck JA, Studer L (2015) Moving stem cells to the clinic: potential and limitations for brain repair. Neuron 86:187-206. https://doi.org/10.1016/j.neuron.2015.03.002

27. Takahashi K, Yamanaka S (2006) Induction of pluripotent stem cells from mouse embryonic and adult fibroblast cultures by defined factors. Cell 126:663-676. https://doi.org/10.1016/j. cell.2006.07.024

28. Doi D, Samata B, Katsukawa M, Kikuchi T, Morizane A, Ono Y, Sekiguchi K, Nakagawa M, Parmar M, Takahashi J (2014) Isolation of human induced pluripotent stem cell-derived dopaminergic progenitors by cell sorting for successful transplantation. Stem Cell Rep 2:337-350. https://doi.org/10.1016/j.stemc r.2014.01.013

29. Kikuchi T, Morizane A, Doi D, Magotani H, Onoe H, Hayashi T, Mizuma H, Takara S, Takahashi R, Inoue H, Morita S, Yamamoto M, Okita K, Nakagawa M, Parmar M, Takahashi J (2017) Human iPS cell-derived dopaminergic neurons function in a primate Parkinson's disease model. Nature 548:592-596. https:// doi.org/10.1038/nature23664

30. Espuny-Camacho I, Michelsen KA, Gall D, Linaro D, Hasche A, Bonnefont J, Bali C, Orduz D, Bilheu A, Herpoel A, Lambert N, Gaspard N, Peron S, Schiffmann SN, Giugliano M, Gaillard A, Vanderhaeghen P (2013) Pyramidal neurons derived from human pluripotent stem cells integrate efficiently into mouse brain circuits in vivo. Neuron 77:440-456. https://doi.org/10.1016/j.neuro n.2012.12.011

31. Tamburini C, Li M (2017) Understanding neurodevelopmental disorders using human pluripotent stem cell-derived neurons. Brain Pathol 27:508-517. https://doi.org/10.1111/bpa.12517

32. Stoker TB, Blair NF, Barker RA (2017) Neural grafting for Parkinson's disease: challenges and prospects. Neural Regen Res 12:389-392. https://doi.org/10.4103/1673-5374.202935

33. Efe JA, Hilcove S, Kim J, Zhou H, Ouyang K, Wang G, Chen J, Ding S (2011) Conversion of mouse fibroblasts into 
cardiomyocytes using a direct reprogramming strategy. Nat Cell Biol 13:215-222. https://doi.org/10.1038/ncb2164

34. Han DW, Greber B, Wu G, Tapia N, Arauzo-Bravo MJ, Ko K, Bernemann C, Stehling M, Scholer HR (2011) Direct reprogramming of fibroblasts into epiblast stem cells. Nat Cell Biol 13:66-71. https://doi.org/10.1038/ncb2136

35. Han DW, Tapia N, Hermann A, Hemmer K, Hoing S, ArauzoBravo MJ, Zaehres H, Wu G, Frank S, Moritz S, Greber B, Yang JH, Lee HT, Schwamborn JC, Storch A, Scholer HR (2012) Direct reprogramming of fibroblasts into neural stem cells by defined factors. Cell Stem Cell 10:465-472. https://doi. org/10.1016/j.stem.2012.02.021

36. Huang P, He Z, Ji S, Sun H, Xiang D, Liu C, Hu Y, Wang X, Hui L (2011) Induction of functional hepatocyte-like cells from mouse fibroblasts by defined factors. Nature 475:386-389. https ://doi.org/10.1038/nature10116

37. Ieda M, Fu JD, Delgado-Olguin P, Vedantham V, Hayashi Y, Bruneau BG, Srivastava D (2010) Direct reprogramming of fibroblasts into functional cardiomyocytes by defined factors. Cell 142:375-386. https://doi.org/10.1016/j.cell.2010.07.002

38. Sekiya S, Suzuki A (2011) Direct conversion of mouse fibroblasts to hepatocyte-like cells by defined factors. Nature 475:390-393. https://doi.org/10.1038/nature10263

39. Szabo E, Rampalli S, Risueno RM, Schnerch A, Mitchell R, Fiebig-Comyn A, Levadoux-Martin M, Bhatia M (2010) Direct conversion of human fibroblasts to multilineage blood progenitors. Nature 468:521-526. https://doi.org/10.1038/nature09591

40. Thier M, Worsdorfer P, Lakes YB, Gorris R, Herms S, Opitz T, Seiferling D, Quandel T, Hoffmann P, Nothen MM, Brustle O, Edenhofer F (2012) Direct conversion of fibroblasts into stably expandable neural stem cells. Cell Stem Cell 10:473-479. https ://doi.org/10.1016/j.stem.2012.03.003

41. Vierbuchen T, Ostermeier A, Pang ZP, Kokubu Y, Sudhof TC, Wernig M (2010) Direct conversion of fibroblasts to functional neurons by defined factors. Nature 463:1035-1041. https://doi. org/10.1038/nature08797

42. Pfisterer U, Wood J, Nihlberg K, Hallgren O, Bjermer L, Westergren-Thorsson G, Lindvall O, Parmar M (2011) Efficient induction of functional neurons from adult human fibroblasts. Cell Cycle 10:3311-3316. https://doi.org/10.4161/cc.10.19.17584

43. Pang ZP, Yang N, Vierbuchen T, Ostermeier A, Fuentes DR, Yang TQ, Citri A, Sebastiano V, Marro S, Sudhof TC, Wernig M (2011) Induction of human neuronal cells by defined transcription factors. Nature 476:220-223. https://doi.org/10.1038/natur e10202

44. Dell'Anno MT, Caiazzo M, Leo D, Dvoretskova E, Medrihan L, Colasante G, Giannelli S, Theka I, Russo G, Mus L, Pezzoli G, Gainetdinov RR, Benfenati F, Taverna S, Dityatev A, Broccoli V (2014) Remote control of induced dopaminergic neurons in parkinsonian rats. J Clin Invest 124:3215-3229. https://doi. org/10.1172/JCI74664

45. Su Z, Niu W, Liu ML, Zou Y, Zhang CL (2014) In vivo conversion of astrocytes to neurons in the injured adult spinal cord. Nat Commun 5:3338. https://doi.org/10.1038/ncomms4338

46. Blanchard JW, Eade KT, Szucs A, Lo Sardo V, Tsunemoto RK, Williams D, Sanna PP, Baldwin KK (2015) Selective conversion of fibroblasts into peripheral sensory neurons. Nat Neurosci 18:25-35. https://doi.org/10.1038/nn.3887

47. Caiazzo M, Dell'Anno MT, Dvoretskova E, Lazarevic D, Taverna S, Leo D, Sotnikova TD, Menegon A, Roncaglia P, Colciago G, Russo G, Carninci P, Pezzoli G, Gainetdinov RR, Gustincich S, Dityatev A, Broccoli V (2011) Direct generation of functional dopaminergic neurons from mouse and human fibroblasts. Nature 476:224-227. https://doi.org/10.1038/nature10284

48. Gascon S, Murenu E, Masserdotti G, Ortega F, Russo GL, Petrik D, Deshpande A, Heinrich C, Karow M, Robertson SP,
Schroeder T, Beckers J, Irmler M, Berndt C, Angeli JP, Conrad M, Berninger B, Gotz M (2016) Identification and successful negotiation of a metabolic checkpoint in direct neuronal reprogramming. Cell Stem Cell 18:396-409. https://doi.org/10.1016/j. stem.2015.12.003

49. Masserdotti G, Gillotin S, Sutor B, Drechsel D, Irmler M, Jorgensen HF, Sass S, Theis FJ, Beckers J, Berninger B, Guillemot F, Gotz M (2015) Transcriptional mechanisms of proneural factors and REST in regulating neuronal reprogramming of astrocytes. Cell Stem Cell 17:74-88. https://doi.org/10.1016/j. stem.2015.05.014

50. Pfisterer U, Kirkeby A, Torper O, Wood J, Nelander J, Dufour A, Bjorklund A, Lindvall O, Jakobsson J, Parmar M (2011) Direct conversion of human fibroblasts to dopaminergic neurons. Proc Natl Acad Sci USA 108:10343-10348. https://doi.org/10.1073/ pnas. 1105135108

51. Son EY, Ichida JK, Wainger BJ, Toma JS, Rafuse VF, Woolf CJ, Eggan K (2011) Conversion of mouse and human fibroblasts into functional spinal motor neurons. Cell Stem Cell 9:205-218. https ://doi.org/10.1016/j.stem.2011.07.014

52. Victor MB, Richner M, Hermanstyne TO, Ransdell JL, Sobieski C, Deng PY, Klyachko VA, Nerbonne JM, Yoo AS (2014) Generation of human striatal neurons by microRNA-dependent direct conversion of fibroblasts. Neuron 84:311-323. https://doi. org/10.1016/j.neuron.2014.10.016

53. Zhang L, Yin JC, Yeh H, Ma NX, Lee G, Chen XA, Wang Y, Lin L, Chen L, Jin P, Wu GY, Chen G (2015) Small molecules efficiently reprogram human astroglial cells into functional neurons. Cell Stem Cell 17:735-747. https://doi.org/10.1016/j. stem.2015.09.012

54. Kim J, Su SC, Wang H, Cheng AW, Cassady JP, Lodato MA, Lengner CJ, Chung CY, Dawlaty MM, Tsai LH, Jaenisch R (2011) Functional integration of dopaminergic neurons directly converted from mouse fibroblasts. Cell Stem Cell 9:413-419. https://doi.org/10.1016/j.stem.2011.09.011

55. Chouchane M, Melo de Farias AR, de Moura DM, Hilscher MM, Schroeder T, Leao RN RN, MR MR (2017) Lineage reprogramming of astroglial cells from different origins into distinct neuronal subtypes. Stem cell reports 9:162-176. https://doi. org/10.1016/j.stemcr.2017.05.009

56. Pereira M, Pfisterer U, Rylander D, Torper O, Lau S, Lundblad M, Grealish S, Parmar M (2014) Highly efficient generation of induced neurons from human fibroblasts that survive transplantation into the adult rat brain. Sci Rep 4:6330. https://doi. org/10.1038/srep06330

57. Colasante G, Lignani G, Rubio A, Medrihan L, Yekhlef L, Sessa A, Massimino L, Giannelli SG, Sacchetti S, Caiazzo M, Leo D, Alexopoulou D, Dell'Anno MT, Ciabatti E, Orlando M, Studer M, Dahl A, Gainetdinov RR, Taverna S, Benfenati F, Broccoli V (2015) Rapid conversion of fibroblasts into functional forebrain GABAergic interneurons by direct genetic reprogramming. Cell Stem Cell 17:719-734. https://doi.org/10.1016/j. stem.2015.09.002

58. Shi Z, Zhang J, Chen S, Li Y, Lei X, Qiao H, Zhu Q, Hu B, Zhou Q, Jiao J (2016) Conversion of fibroblasts to parvalbumin neurons by one transcription factor, ascl1, and the chemical compound forskolin. J Biol Chem 291:13560-13570. https://doi. org/10.1074/jbc.M115.709808

59. Grande A, Sumiyoshi K, Lopez-Juarez A, Howard J, Sakthivel B, Aronow B, Campbell K, Nakafuku M (2013) Environmental impact on direct neuronal reprogramming in vivo in the adult brain. Nat Commun 4:2373. https://doi.org/10.1038/ncomm s3373

60. Liu Y, Miao Q, Yuan J, Han S, Zhang P, Li S, Rao Z, Zhao W, Ye Q, Geng J, Zhang X, Cheng L (2015) Ascll converts dorsal 
midbrain astrocytes into functional neurons in vivo. J Neurosci 35:9336-9355. https://doi.org/10.1523/jneurosci.3975-14.2015

61. Pereira M, Birtele M, Shrigley S, Benitez JA, Hedlund E, Parmar M, Ottosson DR (2017) Direct reprogramming of resident NG2 glia into neurons with properties of fast-spiking parvalbumincontaining interneurons. Stem Cell Reports 9:742-751. https:// doi.org/10.1016/j.stemcr.2017.07.023

62. Torper O, Pfisterer U, Wolf DA, Pereira M, Lau S, Jakobsson J, Bjorklund A, Grealish S, Parmar M (2013) Generation of induced neurons via direct conversion in vivo. Proc Natl Acad Sci USA 110:7038-7043. https://doi.org/10.1073/pnas.13038 29110

63. Thorel F, Nepote V, Avril I, Kohno K, Desgraz R, Chera S, Herrera PL (2010) Conversion of adult pancreatic alpha-cells to beta-cells after extreme beta-cell loss. Nature 464:11491154. https://doi.org/10.1038/nature08894

64. Yang YP, Thorel F, Boyer DF, Herrera PL, Wright CVE (2011) Context-specific $\alpha$-to- $\beta$-cell reprogramming by forced Pdx 1 expression. Genes Dev 25:1680-1685. https://doi.org/10.1101/ gad.16875711

65. Zhou Q, Brown J, Kanarek A, Rajagopal J, Melton DA (2008) In vivo reprogramming of adult pancreatic exocrine cells to beta-cells. Nature 455:627-632. https://doi.org/10.1038/natur e07314

66. Guo Z, Zhang L, Wu Z, Chen Y, Wang F, Chen G (2014) In vivo direct reprogramming of reactive glial cells into functional neurons after brain injury and in an Alzheimer's disease model. Cell Stem Cell 14:188-202. https://doi.org/10.1016/j. stem.2013.12.001

67. Torper O, Ottosson DR, Pereira M, Lau S, Cardoso T, Grealish S, Parmar M (2015) In vivo reprogramming of striatal NG2 glia into functional neurons that integrate into local host circuitry. Cell Rep 12:474-481. https://doi.org/10.1016/j.celrep.2015.06.040

68. Niu W, Zang T, Wang LL, Zou Y, Zhang CL (2018) Phenotypic reprogramming of striatal neurons into dopaminergic neuron-like cells in the adult mouse brain. Stem Cell Reports 11:1156-1170. https://doi.org/10.1016/j.stemcr.2018.09.004

69. Niu W, Zang T, Zou Y, Fang S, Smith DK, Bachoo R, Zhang CL (2013) In vivo reprogramming of astrocytes to neuroblasts in the adult brain. Nat Cell Biol 15:1164-1175. https://doi.org/10.1038/ ncb2843

70. Weinberg MS, Criswell HE, Powell SK, Bhatt AP, McCown TJ (2017) Viral vector reprogramming of adult resident striatal oligodendrocytes into functional neurons. Mol Ther 25:928-934. https://doi.org/10.1016/j.ymthe.2017.01.016

71. di Val Rivetti, Cervo P, Romanov RA, Spigolon G, Masini D, Martin-Montanez E, Toledo EM, La Manno G, Feyder M, Pifl C, Ng YH, Sanchez SP, Linnarsson S, Wernig M, Harkany T, Fisone G, Arenas E (2017) Induction of functional dopamine neurons from human astrocytes in vitro and mouse astrocytes in a Parkinson's disease model. Nat Biotechnol 35:444-452. https ://doi.org/10.1038/nbt.3835

72. Heinrich C, Spagnoli FM, Berninger B (2015) In vivo reprogramming for tissue repair. Nat Cell Biol 17:204-211. https:// doi.org/10.1038/ncb3108

73. Dimou L, Götz M (2014) Glial cells as progenitors and stem cells: new roles in the healthy and diseased brain. Physiol Rev 94:709-737. https://doi.org/10.1152/physrev.00036.2013

74. Malatesta P, Appolloni I, Calzolari F (2008) Radial glia and neural stem cells. Cell Tissue Res 331:165-178. https://doi. org/10.1007/s00441-007-0481-8

75. Hu X, Qin S, Huang X, Yuan Y, Tan Z, Gu Y, Cheng X, Wang D, Lian X-F, He C, Su Z (2019) Stem cell reports article regionrestrict astrocytes exhibit heterogeneous susceptibility to neuronal reprogramming. Stem Cell Rep. https://doi.org/10.1016/j. stemcr.2018.12.017
76. Sirko S, Behrendt G, Johansson PA, Tripathi P, Costa MR, Bek S, Heinrich C, Tiedt S, Colak D, Dichgans M, Fischer IR, Plesnila N, Staufenbiel M, Haass C, Snapyan M, Saghatelyan A, Tsai L-H, Fischer A, Grobe K, Dimou L, Götz M (2013) Reactive glia in the injured brain acquire stem cell properties in response to sonic hedgehog. Cell Stem Cell 12:426-439. https://doi. org/10.1016/j.stem.2013.01.019

77. Magnusson JP, Goritz C, Tatarishvili J, Dias DO, Smith EMK, Lindvall O, Kokaia Z, Frisen J (2014) A latent neurogenic program in astrocytes regulated by Notch signaling in the mouse. Science 346:237-241. https://doi.org/10.1126/scien ce.346.6206.237

78. Moreno-Jiménez EP, Flor-García M, Terreros-Roncal J, Rábano A, Cafini F, Pallas-Bazarra N, Ávila J, Llorens-Martín M (2019) Adult hippocampal neurogenesis is abundant in neurologically healthy subjects and drops sharply in patients with Alzheimer's disease. Nat Med. https://doi.org/10.1038/s41591-019-0375-9

79. Dimou L, Simon C, Kirchhoff F, Takebayashi H, Gotz M (2008) Progeny of Olig2-expressing progenitors in the gray and white matter of the adult mouse cerebral cortex. J Neurosci 28:1043410442. https://doi.org/10.1523/JNEUROSCI.2831-08.2008

80. Paukert M, Bergles DE (2006) Synaptic communication between neurons and NG2 + cells. Curr Opin Neurobiol 16:515-521. https ://doi.org/10.1016/j.conb.2006.08.009

81. Karow M, Sanchez R, Schichor C, Masserdotti G, Ortega F, Heinrich C, Gascon S, Khan MA, Lie DC, Dellavalle A, Cossu G, Goldbrunner R, Gotz M, Berninger B (2012) Reprogramming of pericyte-derived cells of the adult human brain into induced neuronal cells. Cell Stem Cell 11:471-476. https://doi. org/10.1016/j.stem.2012.07.007

82. Popovich PG, Hickey WF (2001) Bone marrow chimeric rats reveal the unique distribution of resident and recruited macrophages in the contused rat spinal cord. J Neuropathol Exp Neurol 60:676-685

83. Matsuda T, Irie T, Katsurabayashi S, Hayashi Y, Nagai T, Hamazaki N, Adefuin AMD, Miura F, Ito T, Kimura H, Shirahige K, Takeda T, Iwasaki K, Imamura T, Nakashima K (2019) Pioneer factor NeuroD1 rearranges transcriptional and epigenetic profiles to execute microglia-neuron conversion. Neuron 101:472-485. https://doi.org/10.1016/j.neuron.2018.12.010

84. Torper O, Gotz M (2017) Brain repair from intrinsic cell sources: turning reactive glia into neurons. Prog Brain Res 230:69-97. https://doi.org/10.1016/bs.pbr.2016.12.010

85. Buffo A, Vosko MR, Ertürk D, Hamann GF, Jucker M, Rowitch D, Götz M (2005) Expression pattern of the transcription factor Olig2 in response to brain injuries: implications for neuronal repair. Proc Natl Acad Sci USA 102:18183

86. Karow M, Camp JG, Falk S, Gerber T, Pataskar A, Gac-Santel M, Kageyama J, Brazovskaja A, Garding A, Fan W, Riedemann T, Casamassa A, Smiyakin A, Schichor C, Götz M, Tiwari VK, Treutlein B, Berninger B (2018) Direct pericyte-to-neuron reprogramming via unfolding of a neural stem cell-like program. Nat Neurosci 21:932-940. https://doi.org/10.1038/s4159 3-018-0168-3

87. Treutlein B, Lee QY, Camp JG, Mall M, Koh W, Shariati SAM, Sim S, Neff NF, Skotheim JM, Wernig M, Quake SR (2016) Dissecting direct reprogramming from fibroblast to neuron using single-cell RNA-seq. Nature 534:391-395. https://doi.org/10.1038/ nature 18323

88. Heinrich C, Blum R, Gascon S, Masserdotti G, Tripathi P, Sanchez R, Tiedt S, Schroeder T, Gotz M, Berninger B (2010) Directing astroglia from the cerebral cortex into subtype specific functional neurons. PLoS Biol 8:e1000373. https://doi. org/10.1371/journal.pbio.1000373

89. Berninger B, Costa MR, Koch U, Schroeder T, Sutor B, Grothe B, Gotz M (2007) Functional properties of neurons derived from 
in vitro reprogrammed postnatal astroglia. J Neurosci 27:86548664. https://doi.org/10.1523/JNEUROSCI.1615-07.2007

90. Arenas E, Denham M, Villaescusa JC (2015) How to make a midbrain dopaminergic neuron. Development 142:1918-1936. https://doi.org/10.1242/dev.097394

91. Addis RC, Hsu FC, Wright RL, Dichter MA, Coulter DA, Gearhart JD (2011) Efficient conversion of astrocytes to functional midbrain dopaminergic neurons using a single polycistronic vector. PLoS One 6:e28719. https://doi.org/10.1371/journ al.pone.0028719

92. Jiang H, Xu Z, Zhong P, Ren Y, Liang G, Schilling HA, Hu Z, Zhang Y, Wang X, Chen S, Yan Z, Feng J (2015) Cell cycle and p53 gate the direct conversion of human fibroblasts to dopaminergic neurons. Nat Commun 6:10100. https://doi.org/10.1038/ ncomms 10100

93. Yoo J, Noh M, Kim H, Jeon NL, Kim BS, Kim J (2015) Nanogrooved substrate promotes direct lineage reprogramming of fibroblasts to functional induced dopaminergic neurons. Biomaterials 45:36-45. https://doi.org/10.1016/j.biomateria 1s.2014.12.049

94. Casarosa S, Fode C, Guillemot F (1999) Mash1 regulates neurogenesis in the ventral telencephalon. Development 126:525-534

95. Fode C, Ma Q, Casarosa S, Ang SL, Anderson DJ, Guillemot $\mathrm{F}$ (2000) A role for neural determination genes in specifying the dorsoventral identity of telencephalic neurons. Genes Dev 14:67-80

96. Liodis P, Denaxa M, Grigoriou M, Akufo-Addo C, Yanagawa Y, Pachnis V (2007) Lhx6 activity is required for the normal migration and specification of cortical interneuron subtypes. J Neurosci 27:3078-3089. https://doi.org/10.1523/jneurosci.3055-06.2007

97. Poitras L, Ghanem N, Hatch G, Ekker M (2007) The proneural determinant MASH1 regulates forebrain Dlx1/2 expression through the I12b intergenic enhancer. Development 134:17551765. https://doi.org/10.1242/dev.02845

98. Niu W, Zang T, Smith DK, Vue TY, Zou Y, Bachoo R, Johnson JE, Zhang CL (2015) SOX2 reprograms resident astrocytes into neural progenitors in the adult brain. Stem Cell Reports 4:780 794. https://doi.org/10.1016/j.stemcr.2015.03.006

99. Brulet R, Matsuda T, Zhang L, Miranda C, Giacca M, Kaspar BK, Nakashima K, Hsieh J (2017) NEUROD1 instructs neuronal conversion in non-reactive astrocytes. Stem Cell Reports 8:1506-1515. https://doi.org/10.1016/j.stemcr.2017.04.013

100. Heinrich C, Bergami M, Gascon S, Lepier A, Vigano F, Dimou L, Sutor B, Berninger B, Gotz M (2014) Sox2-mediated conversion of NG2 glia into induced neurons in the injured adult cerebral cortex. Stem Cell Reports 3:1000-1014. https://doi. org/10.1016/j.stemcr.2014.10.007

101. Rylander D, Bagetta V, Pendolino V, Zianni E, Grealish S, Gardoni F, Di Luca M, Calabresi P, Cenci MA, Picconi B (2013) Region-specific restoration of striatal synaptic plasticity by dopamine grafts in experimental Parkinsonism. Proc Natl Acad Sci USA 110:E4375-E4384. https://doi.org/10.1073/pnas.13111 87110

102. Deisseroth K (2011) Optogenetics. Nat Methods 8:26-29. https ://doi.org/10.1038/nmeth.f.324

103. Vardy E, Robinson JE, Li C, Olsen RH, DiBerto JF, Giguere PM, Sassano FM, Huang XP, Zhu H, Urban DJ, White KL, Rittiner JE, Crowley NA, Pleil KE, Mazzone CM, Mosier PD, Song J, Kash TL, Malanga CJ, Krashes MJ, Roth BL (2015) A new DREADD facilitates the multiplexed chemogenetic interrogation of behavior. Neuron 86:936-946. https://doi.org/10.1016/j.neuro n.2015.03.065

104. Spatazza J, Mancia Leon WR, Alvarez-Buylla A (2017) Transplantation of GABAergic interneurons for cell-based therapy. Prog Brain Res 231:57-85. https://doi.org/10.1016/ bs.pbr.2016.11.005
105. Wickersham IR, Lyon DC, Barnard RJ, Mori T, Finke S, Conzelmann KK, Young JA, Callaway EM (2007) Monosynaptic restriction of transsynaptic tracing from single, genetically targeted neurons. Neuron 53:639-647. https://doi.org/10.1016/j. neuron.2007.01.033

106. Luo C, Lee QY, Wapinski O, Castanon R, Nery JR, Mall M, Kareta MS, Cullen SM, Goodell MA, Chang HY, Wernig M, Ecker JR (2019) Global DNA methylation remodeling during direct reprogramming of fibroblasts to neurons. eLife. https:// doi.org/10.7554/elife.40197

107. Herdy J, Schafer S, Kim Y, Ansari Z, Zangwill D, Ku M, Paquola A, Lee H, Mertens J, Gage FH (2019) Chemical modulation of transcriptionally enriched signaling pathways to optimize the conversion of fibroblasts into neurons. eLife. https:// doi.org/10.7554/elife.41356

108. Nato G, Caramello A, Trova S, Avataneo V, Rolando C, Taylor V, Buffo A, Peretto P, Luzzati F (2015) Striatal astrocytes produce neuroblasts in an excitotoxic model of Huntington's disease. Development 142:840-845. https://doi.org/10.1242/ DEV.116657

109. Kepecs A, Fishell G (2014) Interneuron cell types are fit to function. Nature 505:318. https://doi.org/10.1038/nature12983

110. Kreitzer AC (2009) Physiology and pharmacology of striatal neurons. Annu Rev Neurosci 32:127-147. https://doi. org/10.1146/annurev.neuro.051508.135422

111. Kawaguchi Y, Wilson CJ, Augood SJ, Emson PC (1995) Striatal interneurones: chemical, physiological and morphological characterization. Trends Neurosci 18:527-535

112. Kelsom C, Lu W (2013) Development and specification of GABAergic cortical interneurons. Cell Biosci 3:19. https:// doi.org/10.1186/2045-3701-3-19

113. Rudy B, Fishell G, Lee SH, Hjerling-Leffler J (2011) Three groups of interneurons account for nearly $100 \%$ of neocortical GABAergic neurons. Dev Neurobiol 71:45-61. https://doi. org/10.1002/dneu.20853

114. Tepper JM, Bolam JP (2004) Functional diversity and specificity of neostriatal interneurons. Curr Opin Neurobiol 14:685692. https://doi.org/10.1016/j.conb.2004.10.003

115. Dickie AC, Bell AM, Iwagaki N, Polgar E, Gutierrez-Mecinas M, Kelly R, Lyon H, Turnbull K, West SJ, Etlin A, Braz J, Watanabe M, Bennett DLH, Basbaum AI, Riddell JS, Todd AJ (2018) Morphological and functional properties distinguish the substance $\mathrm{P}$ and gastrin-releasing peptide subsets of excitatory interneuron in the spinal cord dorsal horn. Pain. https://doi. org/10.1097/j.pain.0000000000001406

116. Chohan MO, Moore H (2016) Interneuron progenitor transplantation to treat CNS dysfunction. Front Neural Circuits 10:2. https://doi.org/10.3389/fncir.2016.00064

117. Alonso A, Köhler C (1982) Evidence for separate projections of hippocampal pyramidal and non-pyramidal neurons to different parts of the septum in the rat brain. Neurosci Lett 31:209-214. https://doi.org/10.1016/0304-3940(82)90021-0

118. Thomson AM, Bannister AP (2003) Interlaminar connections in the neocortex. Cereb Cortex 13:5-14

119. Schwartzkroin PA (2012) Chapter 2-Cellular bases of focal and generalized epilepsies. In: Stefan H, Theodore WH (eds) Handbook of clinical neurology. Elsevier, Asterdam, pp 13-33

120. Buzsáki G (1984) Feed-forward inhibition in the hippocampal formation. Prog Neurobiol 22:131-153

121. Yao X-H, Wang M, He X-N, He F, Zhang S-Q, Lu W, Qiu Z-L, Yu Y-C (2016) Electrical coupling regulates layer 1 interneuron microcircuit formation in the neocortex. Nat Commun 7:12229. https://doi.org/10.1038/ncomms12229

122. Tremblay R, Lee S, Rudy B (2016) GABAergic interneurons in the neocortex: from cellular properties to circuits. Neuron 91:260-292. https://doi.org/10.1016/j.neuron.2016.06.033 
123. Fino E, Packer AM, Yuste R (2013) The logic of inhibitory connectivity in the neocortex. Neuroscientist 19:228-237. https://doi.org/10.1177/1073858412456743

124. Tóth K, Freund TF, Miles R (1997) Disinhibition of rat hippocampal pyramidal cells by GABAergic afferents from the septum. J Physiol 500:463

125. Chevalier G, Deniau JM (1990) Disinhibition as a basic process in the expression of striatal functions. Trends Neurosci 13:277-280. https://doi.org/10.1016/0166-2236(90)90109-N

126. Dehorter N, Marichal N, Marín O, Berninger B (2017) Tuning neural circuits by turning the interneuron knob. Curr Opin Neurobiol 42:144-151. https://doi.org/10.1016/j.conb.2016.12.009

127. Tang Y, Stryker MP, Alvarez-Buylla A, Espinosa JS (2014) Cortical plasticity induced by transplantation of embryonic somatostatin or parvalbumin interneurons. Proc Natl Acad Sci USA 111:18339-18344. https://doi.org/10.1073/pnas.1421844112

128. Marin $O$ (2012) Interneuron dysfunction in psychiatric disorders. Nat Rev Neurosci 13:107-120. https://doi.org/10.1038/nrn3155

129. Kato M, Dobyns WB (2005) X-linked lissencephaly with abnormal genitalia as a tangential migration disorder causing intractable epilepsy: proposal for a new term, "interneuronopathy". J Child Neurol 20:392-397. https://doi.org/10.1177/0883073805 0200042001

130. Martinez-Losa M, Tracy TE, Ma K, Verret L, Clemente-Perez A, Khan AS, Cobos I, Ho K, Gan L, Mucke L, Alvarez-Dolado M, Palop JJ (2018) Nav1.1-overexpressing interneuron transplants restore brain rhythms and cognition in a mouse model of Alzheimer's disease. Neuron 98:75-89. https://doi.org/10.1016/j.neuro n.2018.02.029

131. Bode C, Richter F, Sprote C, Brigadski T, Bauer A, Fietz S, Fritschy JM, Richter A (2017) Altered postnatal maturation of striatal GABAergic interneurons in a phenotypic animal model of dystonia. Exp Neurol 287:44-53. https://doi.org/10.1016/j.expne urol.2016.10.013

132. Bakhshi K, Chance SA (2015) The neuropathology of schizophrenia: a selective review of past studies and emerging themes in brain structure and cytoarchitecture. Neuroscience 303:82102. https://doi.org/10.1016/j.neuroscience.2015.06.028

133. Gogolla N, Leblanc JJ, Quast KB, Sudhof TC, Fagiolini M, Hensch TK (2009) Common circuit defect of excitatory-inhibitory balance in mouse models of autism. J Neurodev Disord 1:172-181. https://doi.org/10.1007/s11689-009-9023-x

134. Volk DW, Chitrapu A, Edelson JR, Lewis DA (2015) Chemokine receptors and cortical interneuron dysfunction in schizophrenia. Schizophr Res 167:12-17. https://doi.org/10.1016/j.schre s.2014.10.031

135. Cho RY, Konecky RO, Carter CS (2006) Impairments in frontal cortical gamma synchrony and cognitive control in schizophrenia. Proc Natl Acad Sci USA 103:19878-19883. https://doi. org/10.1073/pnas.0609440103

136. Sohal VS, Zhang F, Yizhar O, Deisseroth K (2009) Parvalbumin neurons and gamma rhythms enhance cortical circuit performance. Nature 459:698-702. https://doi.org/10.1038/natur e07991

137. Gittis AH, Leventhal DK, Fensterheim BA, Pettibone JR, Berke JD, Kreitzer AC (2011) Selective inhibition of striatal fastspiking interneurons causes dyskinesias. J Neurosci 31:1572715731. https://doi.org/10.1523/jneurosci.3875-11.2011

138. Kalanithi PS, Zheng W, Kataoka Y, DiFiglia M, Grantz H, Saper CB, Schwartz ML, Leckman JF, Vaccarino FM (2005) Altered parvalbumin-positive neuron distribution in basal ganglia of individuals with Tourette syndrome. Proc Natl Acad Sci USA 102:13307-13312. https://doi.org/10.1073/pnas.0502624102

139. Kataoka Y, Kalanithi PS, Grantz H, Schwartz ML, Saper C, Leckman JF, Vaccarino FM (2010) Decreased number of parvalbumin and cholinergic interneurons in the striatum of individuals with Tourette syndrome. J Comp Neurol 518:277-291. https:// doi.org/10.1002/cne. 22206

140. Hadar R, Edemann-Callesen H, Reinel C, Wieske F, Voget M, Popova E, Sohr R, Avchalumov Y, Priller J, van Riesen C, Puls I, Bader M, Winter C (2016) Rats overexpressing the dopamine transporter display behavioral and neurobiological abnormalities with relevance to repetitive disorders. Scientific Reports 6:39145. https://doi.org/10.1038/srep39145

141. Hamburg H, Trossbach S V, Bader V, Chwiesko C, Kipar A, Sauvage M, Crum WR, Vernon AC, Bidmon HJ, Korth C (2016) Simultaneous effects on parvalbumin-positive interneuron and dopaminergic system development in a transgenic rat model for sporadic schizophrenia. Scientific Reports 6:34946. doi: 10.1038/ srep34946https://www.nature.com/articles/srep34946\#suppl ementary-information

142. Steinecke A, Gampe C, Nitzsche F, Bolz J (2014) DISC1 knockdown impairs the tangential migration of cortical interneurons by affecting the actin cytoskeleton. Front Cell Neurosci 8:. https ://doi.org/10.3389/fncel.2014.00190

143. Mertens J, Paquola ACM, Ku M, Hatch E, Bohnke L, Ladjevardi S, McGrath S, Campbell B, Lee H, Herdy JR, Goncalves JT, Toda T, Kim Y, Winkler J, Yao J, Hetzer MW, Gage FH (2015) Directly reprogrammed human neurons retain agingassociated transcriptomic signatures and reveal age-related nucleocytoplasmic defects. Cell Stem Cell 17:705-718. https:// doi.org/10.1016/j.stem.2015.09.001

144. Sun AX, Yuan Q, Tan S, Xiao Y, Wang D, Khoo AT, Sani L, Tran HD, Kim P, Chiew YS, Lee KJ, Yen YC, Ng HH, Lim B, Je HS (2016) Direct induction and functional maturation of forebrain gabaergic neurons from human pluripotent stem cells. Cell Rep 16:1942-1953. https://doi.org/10.1016/j.celrep.2016.07.035

Publisher's Note Springer Nature remains neutral with regard to jurisdictional claims in published maps and institutional affiliations. 